\title{
Bacterial indicators and antibiotic resistance of Escherichia coli in groundwater
}

\author{
Laura Gambero ${ }^{1}$, Mónica Blarasin ${ }^{2}$, Susana Bettera ${ }^{3}$, Edel Matteoda ${ }^{4}$ \\ ${ }^{1,3}$ Departamento de Microbiología e Inmunología, Facultad de Ciencias Exactas Físico - Químicas y Naturales, Universidad \\ Nacional de Río Cuarto, CONICET. \\ ${ }^{2,4}$ Departamento de Geología, Facultad de Ciencias Exactas Físico - Químicas y Naturales, Universidad Nacional de Río
} Cuarto.

\begin{abstract}
The aim of this research was to investigate the groundwater quality in El Barreal basin (Córdoba, Argentina), through bacteriological analysis and antibiotic resistance of fecal bacteria indicators and their relationship with geochemical and land uses characteristics. Groundwater samples were collected in 36 wells and the following parameters were determined: major chemical components, heterotrophic plate counts, total and fecal coliforms, Escherichia coli and Pseudomonas aeruginosa. Antibiotic resistance of E. coli was analyzed using standard methods. The chemical and bacteriological analysis showed that more than $80 \%$ of samples were unfit for human consumption. Bacteriological contamination was significant in $36 \%$ of samples. The multivariate analysis between bacterial and geochemical variables explained local contamination conditions, evidenced by the arrival of bacteria and some typical indicators $\left(\mathrm{NO}_{3}{ }_{3}, \mathrm{Cl}^{-}\right.$y $\mathrm{HCO}_{3}{ }^{-}$) to groundwater. No significant correlation between $\mathrm{NO}_{3}^{-}$and bacterial counts was observed, which let us to interpret that part of $\mathrm{NO}_{3}{ }^{-}$contents can be supplied by inorganic fertilizers. Total and fecal coliforms were linked to a local increase of $\mathrm{Cl}$ and $\mathrm{HCO}_{3}$ and a decrease of $\mathrm{pH}$ and dissolved oxygen, indicating the arrival and degradation of organic matter into groundwater. The resistance pattern of total E. coli isolates $(n=12)$ showed that the highest percentages were observed for antibiotics of animal use (ampicillin, tetracycline and cephalothin). The analysis of results revealed the impact of land uses demonstrating that livestock activities are the main punctual contaminant sources in this sedimentary aquifer.
\end{abstract}

Keywords - antibiotics, bacterial contamination, hydrogeochemistry, land uses.

\section{INTRODUCTION}

Groundwater importance lies on its ability to act as a large reservoir of freshwater that provides "buffer storage" during periods of drought [1]. As was stated by the mentioned authors, regardless of its importance, groundwater is often misused, usually poorly understood and rarely well managed. In recent decades there has been increasing concern about the final destination of numerous chemical and biological pollutants (pathogenic bacteria, pesticides, fertilizers, industrial by-products and pharmaceuticals) that have a strong impact on water resources, including groundwater. Specifically in agricultural ecosystems there are potential polluting activities like pesticide and fertilizer uses, dairy farms and concentrated animal operations (CAFOs), especially for cows, pigs and poultry. Escherichia coli is the best indicator of fecal contamination, however the presence in the water does not provide definitive information about its possible origin [2]. This is why phenotypic methods, such as antibiotic resistance profiles of $E$. coli have been used as a tool to elucidate the origin of the contamination in various environments [3]. In rural areas, antibiotics are used in veterinary medicine in a prophylactic way (antiparasites and antibiotics) or as growth promoters (used in subtherapeutic doses), generating selective pressure in indicators of fecal contamination. The use of these compounds, coupled with the increase of animal husbandry in increasingly smaller areas, makes the contamination in rural areas considerably increasing [4].

The groundwater of the South of the Cordoba province (Argentina), almost entirely located in sedimentary aquifers, have been studied for different contamination problems [5]. The need to measure pollution indicators in groundwater is increasingly evident as they are useful for assessing the relationship between environmental variables and the causes and consequences of environmental changes. In this way, it is possible to contribute to the improvement of water resources and environment management. In this context, and taking into account as the main hypothesis that the intensive animal breeding affects in a punctual and more concentrated way the unconfined aquifer, the objective of this research was to carry out an integral study to evaluate the groundwater quality in the Barreal basin (Córdoba, Argentina). Bacteriological parameters and antibiotic resistance of bacteria indicative of fecal contamination were analyzed and linked to hydrogeological, hydrochemical and land use characteristics. 


\section{MAIN CHARACTERISTICS OF THE STUDY AREA}

The Barreal basin $\left(100 \mathrm{~km}^{2}\right)$ is located in La Cruz-Gigena valley, between Comechingones Mountains and Las Peñas Mountains (Córdoba, Argentina). According to Matteoda [6] the geomorphological units and the lithological characteristics of the sediments, have conditioned the dynamics and quality of surface and groundwater. The unconfined aquifer, 10 to $80 \mathrm{~m}$ thick, is lithologically heterogeneous, constituted by loessical sediments (very fine sand and silts), that intercalate with paleochannels (sands and gravels of high permeability). The depth of the water table is very variable, between 0 and $40 \mathrm{~m}$ depth, conditioned mainly by the relief. This aspect and the lithology of the unsaturated zone control the probable arrival of contaminants to the aquifer and its transport, transformation and destination [6]. The climate is dry-subhumid with little to no excess water, with an average annual precipitation of $753 \mathrm{~mm}$, distributed in two noticeable periods, being the wetter from November to March (70\% of the total annual precipitation). The basin is a predominantly rural area in which groundwater is used for human consumption, livestock, irrigation and industrial activities. The main activity is agriculture (soybean, maize and wheat crops) while extensive stockbreeding as well as in CAFOs, is practiced. Taking into account the observed land uses, their spatial distribution and the main features (quantity of animals, effluent lagoon, permanence, etc.), the pig feedlots appears as one of the most important threats to the aquifer contamination.

\section{MATERIALS AND METHODS}

During the field work, land uses were surveyed and 36 water wells were sampled. The collection of groundwater samples was carried out during the wet season (December and February 2008-2009).The following parameters were measured in situ: temperature (T, digital thermometer, in ${ }^{\circ} \mathrm{C}$ ), electrical conductivity (EC, Hanna conductivity meter, in $\mathrm{mS} / \mathrm{cm}$ ) and dissolved oxygen (DO, Orion selective ion electrode, in $\mathrm{mg} / \mathrm{L}$ ). At each sampling site, $1 \mathrm{~L}$ of water was collected in clean plastic bottles for physico-chemical analysis and $500 \mathrm{~mL}$ in sterile containers for bacteriological analysis. The latter were kept at $4^{\circ}$ $\mathrm{C}$ until reaching the laboratory and the determinations were performed within $24 \mathrm{~h}$ post-collection. The sampling activities were carried out according to techniques standardized by APHA [7]. It is important to point that each sample was taken after emptying 3 times each well to ensure the groundwater sample representativeness.

In relation to the bacteriological analysis, the determination of heterotrophic plate counts (HPC) was carried in plate count agar, incubated at $35^{\circ} \mathrm{C}$ during $24 \mathrm{~h}$. The total (TC) and thermotolerant coliforms (fecal coliforms, FC) were determined through the multiple-tube fermentation (MTF) technique. Probability tables (McCrady tables) were used to determine the Most Probable Number (MPN) and to estimate the number of coliform organisms per $100 \mathrm{ml}$ of water. The TC were incubated in Mac Conkey broth at $35^{\circ} \mathrm{C}$ during $24-48 \mathrm{~h}$ and FC in BRILA broth (Brilliant Green Bile Lactose 2\% broth) at $44.5^{\circ} \mathrm{C}$ during $24 \mathrm{~h}$. The presence of $E$. coli was determined in $100 \mathrm{ml}$ of sample in Mac Conkey broth incubated at $35^{\circ} \mathrm{C}$ during 24-48 h. Then, an aliquot was spread onto EMB agar plates and incubated at $35^{\circ} \mathrm{C}$ for $24 \mathrm{~h}$. Isolates were confirmed as $E$. coli by using a series of biochemical tests, including indole, Voges-Proskauer, methyl red tests and the inability to grow on citrate agar (IMViC). The presence of Pseudomonas aeruginosa was determined on a volume of $100 \mathrm{ml}$ of sample in Asparagine broth incubated at $35{ }^{\circ} \mathrm{C}$ during $24-48 \mathrm{~h}$. The isolation was carried out in Cetrimide agar plates and colonies were confirmed by the following biochemical tests: oxidase, growth at $42^{\circ} \mathrm{C}$, and pigments production in agar $\mathrm{P}$ and $\mathrm{F}$. The methodology was carried out according to Standard Methods for Examination of Water and Wastewater [7] and Argentine Food Code (AFC) [8].

After the general bacteriological analysis, the isolated and identified strains of $E$. coli were evaluated for resistance to antibiotics by the plaque diffusion method using 6 antibiotic disks $[9,10]$. They correspond to the drugs most commonly used in the treatment of infections caused by Gram-negative bacilli in both humans and animals and on their use as a food additive and as growth promoters in animals. An E. coli inoculum was prepared in Tripticasa Soya broth of approximately $2 \times 10^{8} \mathrm{cfu} / \mathrm{ml}$ whose turbidity corresponds to tube Number 0.5 of the McFarland scale. Then, $200 \mu \mathrm{l}$ of this cultivation was placed in $5 \mathrm{ml}$ of sterile physiological solution and the optical density $(600 \mathrm{~nm})$ of each mixture was adjusted to about 0.08 . The bacterial suspension was inoculated onto plates with $150 \mathrm{~mm}$ of Mueller Hinton agar and then the commercial antibiotic discs were placed. The plates were incubated at $35^{\circ} \mathrm{C}$ for 18 to $20 \mathrm{~h}$. Diameters (in millimeters) of the clear areas of growth inhibition around each antibiotic disk were measured with a precision caliber. The criterion of sensitivity or resistance to each antimicrobial was determined as established by CLSI (Clinical and Laboratory Standard Institute) [11]. E. coli strain ATCC 25922 was used as a control.

The physico-chemical analysis included the determination of the ions $\mathrm{HCO}_{3}{ }^{-}, \mathrm{SO}_{4}{ }^{2}, \mathrm{Cl}^{-}, \mathrm{Na}^{+}, \mathrm{K}^{+}, \mathrm{Ca}^{++}, \mathrm{Mg}^{++}$and $\mathrm{NO}_{3}{ }^{-}$which were analyzed following APHA [7] standard techniques. Finally, the statistical analysis was made using the SSPS v.11.5 package. The multivariate analysis was performed using the factorial method by principal components (PC) to determine 
possible relationships between bacterial contents (TC and FC) and physico-chemical variables. The variable TDS (total dissolved salts) was not considered in the multivariate analysis, because it is represented by the EC.

\section{RESULTS AND DisCUSSION}

The physical-chemical results indicate that $22 \%$ of the samples were not suitable for human consumption, due to nitrate values and/or total salts established in AFC, although Matteoda et al. [6] indicate that 89\% is not apt if Arsenic and Fluorine values are considered. The EC values, which explain the water salinity, were between 670 and $5.830 \mu \mathrm{S} / \mathrm{cm}$. Table 1 shows the statistics of the different chemical components in groundwater. The geochemical composition allowed defining six geochemical groups of groundwater: sodium bicarbonate $(38.8 \%)$, sodium sulphate $(27.7 \%)$, sodium bicarbonate-sulphate $(13.8 \%)$, sodium chloride-sulphate $(5.5 \%)$ and calcium bicarbonate $(2.7 \%)$. They are close related to the geomorphological environments in the studied basin [6].

TABLE 1

STATISTICS OF PHYSICOCHEMICAL PARAMETERS IN GROUNDWATER $\left(\mathrm{mg} / \mathrm{L}, \mathrm{EC}\right.$ in $\mu \mathrm{S} / \mathrm{cm}$ and $\mathrm{T}$ in $\left.{ }^{0} \mathrm{C}\right)$

\begin{tabular}{|c|c|c|c|c|}
\hline Parameters & Minimum & Maximum & Average & Typical deviation \\
\hline $\mathbf{D O}$ & 2 & 11 & 7.90 & 1.76 \\
\hline $\mathbf{p H}$ & 7.49 & 8.80 & 8.12 & 0.39 \\
\hline $\mathbf{T}$ & 18.00 & 22.30 & 20.25 & 1.13 \\
\hline $\mathbf{E C}$ & 670.00 & 5830.00 & 1847.86 & 1152.08 \\
\hline $\mathbf{T D S}$ & 469.00 & 4081.00 & 1293.51 & 806.45 \\
\hline $\mathbf{C O}_{\mathbf{3}}{ }^{-}$ & 0.00 & 21.80 & 4.03 & 6.77 \\
\hline $\mathbf{H C O}_{\mathbf{3}} \mathbf{S}^{-}$ & 207.50 & 1182.50 & 434.51 & 179.15 \\
\hline $\mathbf{S O}_{\mathbf{4}} \mathbf{C l}^{-}$ & 19.30 & 2565.90 & 454.94 & 480.15 \\
\hline $\mathbf{N a}^{+}$ & 8.60 & 1028.60 & 86.03 & 175.39 \\
\hline $\mathbf{K}^{+}$ & 36.40 & 1071.80 & 349.04 & 228.50 \\
\hline $\mathbf{C a}^{++}$ & 6.20 & 49.20 & 15.53 & 8.72 \\
\hline $\mathbf{M g}^{++}$ & 2.80 & 354.40 & 60.60 & 84.38 \\
\hline $\mathbf{N O}^{-}$ & 0.10 & 182.40 & 18.60 & 30.60 \\
\hline & 0.00 & 297.00 & 33.35 & 51.94 \\
\hline
\end{tabular}

TABLE 2

BACTERIOLOGICAL GROUNDWATER QUALITY

\begin{tabular}{|c|c|c|c|c|}
\hline \multirow{4}{*}{ Samples $(\mathrm{n}=36)$} & $\begin{array}{c}\text { Bacteriological } \\
\text { parameters }\end{array}$ & $\begin{array}{c}\text { Limits according to } \\
\text { AFC }\end{array}$ & Min-Max & $\begin{array}{c}\text { Samples numbers } \\
\text { above the limit of } \\
\text { AFC }(\%)\end{array}$ \\
\cline { 2 - 5 } & HPC $(\mathrm{cfu} / \mathrm{mL})$ & No $>500$ & $0-2 \times 10^{4}$ & $14(38 \%)$ \\
\cline { 2 - 5 } & TC $(\mathrm{MPN} / 100 \mathrm{~mL})$ & $\leq 3$ & $0-5 \times 10^{4}$ & $30(83 \%)$ \\
\cline { 2 - 5 } & E. coli & Absence & - & $9(25 \%)$ \\
\cline { 2 - 5 } & Ps. aeruginosa & Absence & - & $8(22 \%)$ \\
\hline
\end{tabular}

HPC: heterotrophic plate counts, TC: total coliforms, AFC: Argentine Food Code

The bacteriological analysis revealed that $83 \%$ of the samples were not suitable for human consumption according to AFC (2012) (Table 2). FC counts were observed in 5 samples (14\%) and the highest value was $1 \times 10^{3}$ MPN/100 mL. From the total samples, 13 (36\%) were the most contaminated (SC3, SC4, B8b, B11, B15, B23, B39, B42, B43, B44, B45, B46, B63), showing TC above $4 \mathrm{MPN} / 100 \mathrm{~mL}$, in some cases FC above $9 \mathrm{MPN} / 100 \mathrm{~mL}$ and presence of E. coli. These results highlight the vulnerability of the aquifer in some places, where the water table is closer to the land surface or the sediments of the unsaturated zone have high hydraulic conductivity, situations that allow the rapid transport of contaminants towards the aquifer. The high percentages of samples with a high TC count, as well as the detection of fecal contamination bacteria (fecal coliforms and E. coli), reveal the probable existence of pathogenic microorganisms in groundwater since the transmission of pathogenic strains of $E$. coli by means of drinking water is well documented [12].

The counts of TC, FC and presence of $E$. coli were compared with land use in each well site. For this purpose, the wells were categorized according the surrounding land uses: those adjacent to livestock activity and/or presence of septic wells (punctual contamination, PC) and those with only surrounding agricultural activities (diffuse pollution, DC). The results showed that in 
the PC wells (especially surrounded by porcine and bovine pens) the TC and FC bacteria counts were highest, as well as the presence of E. coli. On the other hand, in DC wells, none of the indicators of fecal contamination were observed and TC counts were only found in few wells. The relationships between land uses and bacterial counts showed that the major bacterial contamination was related to punctual contamination where the higher contaminant load has allowed the bacteria to avoid the different processes of attenuation in the unsaturated zone, occurring then the percolation of contaminated water to the aquifer.

\begin{tabular}{|c|c|c|c|c|c|}
\hline & & & Compo & ent & \\
\hline & & 1 & 2 & 3 & 4 \\
\hline & DO &,- 292 &,- 644 &,- 327 & , 105 \\
\hline & TC & 267, &, 573 & ,594 &,- 181 \\
\hline $\mathrm{ca}$ & FC &,- 055 & ,630 & 082 & , 153 \\
\hline & pH & ,131 &,- 714 & 090 & ,072 \\
\hline $\bar{\Xi}$ & EC & ,906 & ,035 & ,359 & , 126 \\
\hline$\frac{\bar{a}}{z}$ & $\mathrm{HCO}_{3}^{-}$ &,- 053 &,- 007 & 893 & ,119 \\
\hline & $\mathrm{SO}_{4}{ }^{=}$ & ,941 &,- 127 &,- 090 &,- 047 \\
\hline & $\mathrm{Cl}^{-}$ & ,377 &, 571 & ,656 &,- 170 \\
\hline & $\mathbf{N a}^{+}$ & 844 & 042 & , 490 &,- 011 \\
\hline & $\mathbf{K}^{+}$ &, 743 & ,425 & ,374 &,- 094 \\
\hline & $\mathbf{C a}^{++}$ &, 805 & ,486 &, 056 &,- 220 \\
\hline omponent 1 & $\mathbf{M g}^{++}$ &, 838 &,- 175 &,- 394 & 077 \\
\hline & $\mathrm{NO}_{3}^{-}$ & ,008 &,- 005 & 020 & 963 \\
\hline $\begin{array}{l}\text { FIGURE 1: THE PRINCIPAL COMPONENTS OBTAINED FOR THE } \\
\text { BACTERIAL AND PHYSICO-CHEMICAL VARIABLES IN THE EL } \\
\text { BARREAL BASIN. STANDARDIZATION WITH KAISER }\end{array}$ & & & & & \\
\hline
\end{tabular}

In relation to geochemical and bacteriological indicators relationships, it may be highlighted that the linear correlations between TC and FC vs. nitrate values were statistically non-significant ( $r=-0.105$ and $r=-0.28$ ). The multivariate statistical analysis (Table 3 and Figure 1) showed that $81.4 \%$ of the total variance is explained by four principal components (PC) with the following constitution: The first $\mathrm{PC}$, which explains $43.8 \%$ of the total variance, is formed by $\mathrm{EC}, \mathrm{SO}_{4}^{-}, \mathrm{Na}^{+}, \mathrm{K}^{+}, \mathrm{Ca}^{2+}$ and $\mathrm{Mg}^{2+}$ and it explains the mineralization of water. Specifically, it includes the variables that define the natural background of the physico-chemical groundwater composition, mainly influenced by the relief, lithology and hydrodynamic factors of the basin that control the mineral weathering and the passage of solutes to the solution [6]. The others PC, which account for a low proportion of the total variance, represent more local pollution processes. The second PC ( $20.1 \%$ of total variance), is formed by 2 subgroups that show negative correlation, $\mathrm{DO}$ and $\mathrm{pH}$ opposed to $\mathrm{FC}, \mathrm{TC}$ and $\mathrm{Cl}^{-}$. This component allows us to interpret that low DO and $\mathrm{pH}$ values, good indicators of contamination from organic matter, which consume oxygen and acidify the groundwater, are correlated with high bacteria and $\mathrm{Cl}^{-}$values. The latter is a conservative solute in groundwater and an adequate indicator of contamination derived from urine in livestock scenarios. The third PC, which represents only $10 \%$ of the total variance, is formed by $\mathrm{HCO}_{3}{ }^{-}$and $\mathrm{Cl}^{-}$, weakly associated with TC. It may be interpreted that this component represents local contamination situations. The increase of $\mathrm{HCO}_{3}{ }^{-}$is an indicator of the incorporation of $\mathrm{CO}_{2}$ by biological activity and / or by the arrival of organic matter derived, for example, from excreta. In the regional aquifer, which shows an oxidizing state [5] the organic matter degrades to $\mathrm{CO}_{2}$ and $\mathrm{H}_{2} \mathrm{O}$, lowering the $\mathrm{pH}$. The fourth $\mathrm{PC}$ ( $7.3 \%$ of variance) was expressed only by $\mathrm{NO}_{3}^{-}$. This is a good indicator of contamination since, if they found values are higher than the "natural regional background" (generally less than $10 \mathrm{mg} / \mathrm{L},[13]$ ), there is an evidence of the contamination arrival to the aquifer. $\mathrm{NO}_{3}{ }^{-}$values may be derived from livestock and human fecal residues, organic and inorganic fertilizers, among others. In this study, it was observed that the samples presented a wide range of nitrate values, surpassing the range of the natural regional background. However, when $\mathrm{NO}_{3}{ }^{-}$was related to the TC and $\mathrm{FC}$ variables, no correlation was observed between these indicators, which indicates that the detection of bacteria does not necessarily explain the presence of high $\mathrm{NO}_{3}{ }^{-}$values, and that this compound may has inorganic origin, for example fertilizers, as Piccone et al. [14] state. In the regional 
agroecosystems, Giuliano Albo et al. [15] traced the $\mathrm{NO}_{3}{ }^{-}$origin using isotopic tools, defining that both agriculture and livestock sources can contaminate aquifers with $\mathrm{NO}_{3}{ }^{-}$although the higher values are related to cattle.

Taking into consideration the pattern of antibiotic resistance, we evaluated a total of 12 E. coli strains which were isolated from 9 wells. All isolates were resistant to one or more antibiotics. 25\% was resistant for AMP and the unique strain resistant to TET was that isolated from the B8b well, located downstream of a pig farm in which the use of tetracycline was detected. In addition, another E. coli strain was isolated from the lagoon located in this pig CAFO which also showed resistance to TET. Regarding the rest of the antibiotics analyzed, 17\% showed resistance for CEF, while $100 \%$, 92\% and $92 \%$ respectively, were sensitive for CIP, AMC and CHL (Table 4). The pattern of antibiotic resistance showed that the highest percentages of resistance were observed for AMP, results that coincide with those of Sapkota et al. [16]. Ampicillin is an approved antibiotic by FDA (Food and Drug Administration) and is used in pigs as a therapeutic agent. TET is the most commonly used antibiotic in veterinary medicine and is also administered as a feed additive in a non-therapeutic form as a growth promoter [17]. Interestingly, results published by Fluckey et al. [18] showed that oral TET reduced susceptibility to AMP when they studied resistance to antibiotics in $E$. coli isolated from poultry and pigs. On the other hand, the percentages of resistance for cephalothin observed in this research were relevant. All these aspects should be highlighted, since few authors have investigated the presence of resistant bacteria in groundwater [19].

\section{TABLE 4}

\section{TESTED ANTIBIOTICS AND RESISTANCE PATTERNS}

\begin{tabular}{|c|c|c|c|c|c|c|}
\hline $\begin{array}{c}\text { Antibiotics } \\
\text { abbreviation) }\end{array}$ & \multicolumn{2}{|c|}{${ }^{\mathrm{a}}$ Use } & \multicolumn{2}{c|}{ Disk concentration $(\boldsymbol{\mu g})$} & \multicolumn{2}{c|}{ Resistance pattern of $\boldsymbol{E}$. coli $(\mathbf{n}=\mathbf{1 2})$} \\
\hline & Human & Veterinary & & $\mathbf{R}$ & $\begin{array}{c}\text { \% } \\
\text { I }\end{array}$ & $\mathbf{S}$ \\
\hline Ampicillin (AMP) & ++ & ++ & 10 & 25 & 50 & 25 \\
\hline Tetracycline (TET) & + & ++ & 30 & 8 & 8 & 84 \\
\hline Cephalotine (CEF) & ++ & + & 30 & 17 & 17 & 66 \\
\hline Ciprofloxacin (CIP) & ++ & - & 5 & 0 & 0 & 100 \\
\hline $\begin{array}{c}\text { Amoxicillin + clavulanic } \\
\text { acid (AMC) }\end{array}$ & ++ & - & 10 & 0 & 8 & 92 \\
\hline $\begin{array}{c}\text { Chloramphenicol } \\
\text { (CHL) }\end{array}$ & ++ & - & 30 & 0 & 8 & 92 \\
\hline
\end{tabular}

${ }^{a}$ Frequencies of use of antibiotics in human or animal medicine for Argentina are based on data provided by Laplumé (2011) report published by the X Argentine Congress of the Argentine Society of Infectious Diseases: not used (-), little used (+/-), used (+) and widely used (++).

R: resistance, I: intermediate, $S$ : sensitive

\section{CONCLUSION}

The relationship between bacteriological indicators and physical-chemical parameters with hydrogeological characteristics and land uses shows that the physical and chemical composition of groundwater is partially modified by human activities, which also induce the arrival of bacteria. This research shows that a high percentage of groundwater samples in the studied basin is unfit for human consumption. The results demonstrate the arrival of different pollutants to the groundwater, including some typical contamination tracers such as $\mathrm{NO}_{3}{ }^{-}$, which show values above the regional natural background. Also, high $\mathrm{Cl}^{-}$values were associated with bacteria, which allow to link pollution to livestock activity. The slight acidification of the medium and increase of $\mathrm{HCO}_{3}{ }^{-}$associated to coliform bacteria in sectors of livestock activity also shows the local impact of fecal residues.

The presence of indicator bacteria of fecal contamination which are resistant to ampicillin, tetracycline and cephalothin antibiotics confirmed that the bacterial contamination in water comes almost exclusively from animal waste. The bacteria arrival to the aquifer is highly variable depending on the contamination scenario and the hydrogeological characteristics of each sector of the basin, higher in areas where the water table is near the land surface.

From what has been explained, it is considered that livestock activity is the main source of punctual pollution in the sedimentary aquifer. However, there is a general diffuse chemical contamination, fundamentally represented by the varied $\mathrm{NO}_{3}{ }^{-}$values in the whole basin, which may be fundamentally associated to the extended use of fertilizers. 
The isolation of $E$. coli resistant to antibiotics in the unconfined aquifer of the Barreal basin represents an important contribution in the study of antibiotic resistance, since the selection, dissemination and persistence of resistant bacteria is an increasing problem that limits the effectiveness of antibiotic therapy.

\section{ACKNOWLEDGEMENT}

This work was supported by PID 35/08, PICT 474/15 and Secyt UNRC.

\section{REFERENCES}

[1] B. L. Morris, A. R. L. Lawrence, P. J. C. Chilton, B. Adams, R. C. Calow, and B. A. Klinck, "Groundwater and its Susceptibility to Degradation: A Global Assessment of the problem and options for management”. Early Warning and Assessment Report Series, RS. 03-3. United Nations Environment. 2003.

[2] A. Ibekwe, S. Murinda, and A. Graves, "Genetic diversity and antimicrobial resistance of Escherichia coli from human and animal sources uncovers multiple resistances from human sources". PLoS ONE, 6, 20819. doi:10.1371/journal.pone.0020819. 2011.

[3] W. Ksoll, S. Ishii, M.J. Sadowsky, and R. Hicks, "Presence and sources of fecal coliform bacteria in epilithic periphyton communities of Lake Superior". Applied and Env. Microbiology 73 (12), 3771-3778. 2007. DOI:10.1128/AEM.02654-06.

[4] A. Pruden, Occurrence and transport of antibiotics from CAFOs. In: Hormones and pharmaceuticals generated by concentrated animal feeding operations transport in water and soil. Emerging Topics in Ecotoxicology (Shore L., y Pruden A., Eds.). Springer Dordrecht Heidelberg London, New York, USA, 2009, pp, 63-70.

[5] M. Blarasin, A. Cabrera, and E. Matteoda, “Aguas subterráneas de la provincia de Córdoba”. Edición Unirio.ebook, Río Cuarto, Córdoba Argentina, 2014, p 147.

[6] E. Matteoda, M. Blarasin, and A. Cabrera, "Hidrogeoquímica de un acuífero freático sedimentario y su relación con aspectos dinámicos, modelación geoquímica y procesos de mezcla. Córdoba, Argentina”. Calidad y Contaminación de Agua Subterráneas, Salta, Argentina, 2011, pp 236-243.

[7] APHA, AWWA y WPCF. Standard methods for the examination of water and wastewater. American Public Health Association \& Eaton, Andrew D \& Water Environment Federation \& American Water Works Association. Manual, Washington, D.C. 2005.

[8] AFC. Argentine Food Code. Drinks water, water and aerated water. Chapter XII Art 982. ANMAT, Buenos Aires, Argentina. 2012.

[9] A. Bauer Kirby, J. Sherris, and M. Turck, Antibiotic susceptibility testing by a standardized single disk method. Amer. J. Clin. Pathol. 45:493-96. 1996.

[10] M.L. Gambero, M. Blarasin, S. Bettera, 2016. "Tracking contamination: antibiotic resistance and molecular characteristics of Escherichia coli isolated from groundwater in an agroecosystem". Argentina Rend. Online Soc.Geol. It., 39(1) 829. Società Geologica Italiana, Roma. DOI10.3301/ROL.2016.63. 2016.

[11] CLSI. Clinical and Laboratory Standards Institute. M100S 26th ed., 2016.

[12] B. Mull, and V. Hill, "Recovery and detection of Escherichia coli O157:H7 in surface water, using ultrafiltration and Real-Time PCR". Applied and Environmental Microbiology 75, (11) 3593-3597. 2009. DOI:10.1128/AEM.02750-08.

[13] M.J. Giuliano Albo, and M. Blarasin, "Hidrogeoquímica y estimación del fondo natural de nitratos del agua subterránea en un agroecosistema del pedemonte de la sierra de Comechingones". Revista de la Asociación Geológica Argentina, 71 (3), 378-392. 2014. Online http://ppct.caicyt.gov.ar/index.php/raga/article/view/3096/4349.

[14] L. I. Picone, Y. Andreoli, J. Costa, V. Aparicio, L. Crespo, J. Nanninni, and W. Tambasio, "Evaluación de nitratos y bacterias coliformes en pozos de la cuenca alta del arroyo pantanoso (Bs. As.)". Rev. Invest. Agrop 32, 99-110, 2003.

[15] J. Giuliano Albo, M. Blarasin, and H. Panarello, "Evaluación de la geoquímica e isótopos del nitrato en el acuífero libre de una llanura con actividad agropecuaria, Córdoba, Argentina". Ingeniería, Revista Académica de la FI-UADY 19, 24-38, 2015.

[16] A. Sapkota, F. Curriero, K. Gibson, and K. Schwab, "Antibiotic-resistant Enterococci and fecal indicators in surface water and groundwater impacted by concentrated swine feeding operation". Environ Health Perspect 115 (7), 1040-1045, 2007. DOI:10.1289/ehp.9770.

[17] T. Alexander, L.J. Yanke, E. Topp, M.E. Olson, R. Read, D.W. Morck, and T.A. McAllister, "Effect of subtherapeutic administration of antibiotics on the prevalence of antibiotic-resistant Escherichia coli bacteria in feedlot Cattle". Applied and Environmental Microbiology 74 (14), 4405-4416, 2008. DOI:10.1128/AEM.00489-08.

[18] W. M. Fluckey, W. Loneragan, R. Warner, and M.M. Brashears, "Antimicrobial drug resistance of Salmonella and Escherichia coli isolates from cattle feces, hides, and carcasses”. J. Food Prot 70 (3), 551-556, 2007.

[19] M. Anderson, J. Whitlock, and V. Harwood, "Diversity and distribution of Escherichia coli genotypes and antibiotic resistance phenotypes in feces of humans, cattle and horse. Applied and Environmental Microbiology 72 (11), 6914-6922, 2006. DOI:10.1128/AEM.01029-06. 